\title{
Comparative analysis of Monilinia fructicola and M. laxa isolates from Brazil: monocyclic components of peach brown rot
}

\author{
Sthela Siqueira Angeli ${ }^{1}$ Louise Larissa May De Mio ${ }^{2}$ Lilian Amorim
}

${ }^{1}$ Escola Superior de Agricultura Luiz de Queiroz, Universidade de São Paulo (USP), Piracicaba, SP, Brasil.

${ }^{2}$ Universidade Federal do Paraná, Rua dos Funcionários, 1540, 80035-050, Curitiba, PR, Brasil. E-mail: maydemio@ufpr.br. Corresponding author.

\begin{abstract}
Brown rot is the most important disease of peaches in Brazil. The objective of this study was to compare the brown rot monocyclic components from Monilinia fructicola and M. laxa isolates from Brazil on peaches, due to the detection of M. laxa in the São Paulo production area. Conidia germination and pathogen sporulation were assessed in vitro under a temperature range of 5-35 ${ }^{\circ} \mathrm{C}$ and wetness duration of 6-48h Incubation and latent periods, disease incidence, disease severity and pathogen reproduction on peach fruit were evaluated under 10, 15, 20, 25 and $30^{\circ} \mathrm{C}$ and wetness duration of 6, 12 and $24 \mathrm{~h}$. Six of seven parameters of a generalised beta function fitted to conidia germination of M. fructicola and M. laxa were similar. Only the shape parameter was higher for $M$. fructicola indicating that the range of temperatures and wetness periods favourable for germination is wider for M. laxa than for $M$. fructicola. The optimum temperature for brown rot development caused by M. fructicola was $24.5^{\circ} \mathrm{C}$ and for. Monilinia laxa was $19.8^{\circ} \mathrm{C}$. At $10^{\circ} \mathrm{C} \mathrm{M}$. laxa lesions produced more conidia than M. fructicola, and the opposite occurred at $30^{\circ} \mathrm{C}$. The estimated maximum temperature for lesion development was also higher for M. fructicola than for M. laxa. M. fructicola is favored by warmer weather than M. laxa and the presence and impact of this specie in Brazil must be investigated especially in the South states. Key words: epidemiology, Prunus; Monilia, disease monocycle.
\end{abstract}

Análise comparativa de isolados de Monilinia fructicola e M. laxa do Brasil: componentes monocíclicos da podridão parda

RESUMO: Podridão parda é a doença mais importante de pêssegos no Brasil. O objetivo deste estudo foi comparar os componentes monocíclicos da podridão parda de isolados brasileiros de M. fructicola e M. laxa, devido à detecção de M. laxa em uma área de produção de São Paulo. A germinação de conídios e esporulação do patógeno foram avaliadas in vitro sob uma faixa de temperatura de 5-35 ${ }^{\circ} \mathrm{C}$ e duração do molhamento de 6-48h. Os periodos de incubação e de latência, a incidência da doença, a severidade da doença e a reprodução do patógeno em frutos de pêssego foram avaliados em 10, 15, 20, 25 e 30 ${ }^{\circ} \mathrm{C}$ e duração de molhamento de 6, 12 e $24 \mathrm{~h}$. Seis dos sete parâmetros de uma função beta generalizada para germinação de conídios de $M$. fructicola e M. laxa foram semelhantes. Apenas o parâmetro de forma foi mais alto para M. fructicola indicando que a gama de temperaturas e periodos de molhamento favoráveis para germinação é maior para M. laxa do que para $M$. fructicola. A temperatura ideal para o desenvolvimento de podridão parda causada por $M$. fructicola foi $24,5^{\circ} \mathrm{C}$ e para $\mathrm{Monilinia}$ laxa foi $19,8^{\circ} \mathrm{C}$. A $10^{\circ} \mathrm{C}$ lesões de M. laxa produziram mais conídios que as de M. fructicola, e o inverso ocorreu a $30^{\circ} \mathrm{C}$. A temperatura máxima estimada para o desenvolvimento de lesões também foi maior para $M$. fructicola do que para M. laxa. M. fructicola é favorecido por um clima mais quente do que M. laxa e a presença e impacto deste patógeno no Brazil deve ser acompanhado em especial no estados do sul do país. Palavras-chave: epidemiologia, Prunus; Monilia, doença, monociclo.

\section{INTRODUCTION}

Brown rot is the most important disease of Prunus species in Brazil (MAY DE MIO et al. 2011). The main Monilinia species related to the disease are $M$. fructigena Honey, M. laxa (Aderh. \& Ruhland) Honey and M. fructicola (G. Winter) Honey. M. fructigena occurs mainly in pome and stone fruits in the European Union territory (EU) and has been eradicated in the United States (OGAWA et al., 1995). Monilinia laxa is common in the EU and can also be reported in South Africa, Chile, Iraq, United States (EFSA, 2011). Monilinia fructicola is reported to be a serious pathogen in North and South America, Japan, New Zealand and
Australia (OGAWA et al., 1995; EFSA, 2011). In addition, it has been spreading in the EU since 2001 (EFSA, 2011). In Brazil, M. fructicola was reported in all stone fruit production areas (MAY-DE MIO et al., 2011; LICHTEMBERG et al., 2016) on peaches, plums and nectarines. Detection of M. laxa in São Paulo State was performed in 2007 (SOUZA et al., 2008). From 2008 to 2011, the frequency of Monilinia species was monitored annually in the peach producing areas in Brazil and there was no spread detected of $M$. laxa (LICHTEMBERG et al., 2016). However, M. laxa has been detecting in imported fruit from 2013 to 2015 (unpublished data) and the impact and relevance of these remains unknown and should be investigated. 
A shift in the population of Monilinia spp. from M. laxa to M. fructicola was observed in the USA during the 1980s on diseased prunes and apricots (MICHAILIDES et al., 1987). In Spain a shift in the populations of Monilinia spp. was observed in 2008 when M. fructicola displaced $M$. laxa in some orchards (VILLARINO et al., 2012). In Brazil, the detection of M. laxa in orchards where M. fructicola is already present can lead to a change in disease behaviour. Conditions favourable to $M$. fructicola infection are not necessarily the same as those for M. laxa. Scattered information on the effect of temperature on monocyclic components of this disease has been published (PHILLIPS, 1984; BIGGS \& NORTHOVER, 1988a; WATSON et al., 2002), but no comparative study of the effect of different temperature and wetness duration across different Monilinia peach pathogens from Brazil has been performed. The objective of this study was to assess the effect of different wetness periods and incubation temperatures on the development of brown rot monocycle caused by M. fructicola and $M$. laxa on peaches.

\section{MATERIALS AND METHODS}

Isolation of Monilinia spp. was performed by aseptic transfer to culture media (PDA) of conidia produced by symptomatic peaches collected from naturally infected fruit from commercial orchards in São Paulo State, Brazil. The isolates were collected from the main production area of São Paulo (Paranapanema, Jundiaí and Jarinu municipalities). Isolates ISMf1 and ISMf2, collected in orchards at Jarinu municipality, SP, Brazil (238'23"S, $\left.46^{\circ} 42^{\prime} 55^{\prime \prime} \mathrm{W}\right)$, and the isolates ISMf3 and ISMf4, collected at Paranapanema municipality, SP, Brazil (2323'16"S, 48 $\left.43^{\circ} 36^{\prime \prime} \mathrm{W}\right)$, were identified as $M$. fructicola by morphological characteristics and by PCR using species-specific primers (CÔTÉ et al., 2004). The isolate ESALQ1 was obtained from rotted fruit from an orchard located at Jundiaí municipality, SP, Brazil (2304'35'S, 4647'14”W) and identified as M. laxa by SOUZA et al. (2008). The PCR reactions were performed with a common reverse primer (MO368-S) and the species-specific forward primers MO368-10R (M. fructicola) and laxa-R2 (M. laxa) (CÔTÉ et al., 2004). As the population of $M$. laxa remained restricted to the area where it has been detected, the isolate named as ESALQ1 represents this population. Isolates of $M$. fructicola represented the main area of SP production and were chosen by geographic distance.
All isolates were cultivated on potato-dextrose-agar (PDA) at $20^{\circ} \mathrm{C}$ under a $12 \mathrm{~h}$ photoperiod.

Conidia germination and sporulation of Monilinia isolates under different temperatures and wetness duration

Conidia suspensions were obtained from 7-day-old colonies grown on PDA under a photoperiod of $12 \mathrm{~h}$ and prepared with sterile distilled water. Three drops $\left(30 \mu \mathrm{L}\right.$ each) of $10^{5}$ conidia $\mathrm{mL}^{-1}$ suspension from each culture were placed separately in polystyrene Petri dishes into a Gerbox ${ }^{\circledR}$ with moistened filter paper. The Gerbox $^{\circledR}$ were kept in growth chambers (Eletrolab ${ }^{\circledR}$, São Paulo, SP, Brazil) at 5, 10, 15, 20, 25, 30 and $35^{\circ} \mathrm{C}$ for $6,12,24,36$ and $48 \mathrm{~h}$ of wetness duration. After each interval, $20 \mu \mathrm{L}$ of lactoglycerol was placed on each drop of the spore suspension, and conidial germination was estimated. The number of germinated conidia was counted by observing 100 conidia in each drop under an optical microscope (400x). Three replications were used in each treatment, and the experiment was performed twice.

Sporulation of each isolate was assessed from 7-day-old colonies on PDA which were previously incubated at $5,10,15,20,25,30$ and $35^{\circ} \mathrm{C}$. Mycelial discs of $0.5 \mathrm{~cm}$ diameter were removed from within $1 \mathrm{~cm}$ of the colony centre, randomly selected, and transferred to glass tubes with $5 \mathrm{~mL}$ of sterile water. Tubes were vortexed for 30 seconds, the mycelial discs were removed, and $30 \mu \mathrm{L}$ of lactoglycerol was added to the conidia suspension. Sporulation of two isolates (ISMf1 and ESALQ1) was also assessed in 7-day-old lesions on fruit, following the same methodology described for the colonies in PDA. Conidia concentration was estimated using a hemocytometer. Experiments had 5 replications each and were performed twice.

\section{Incidence and severity of brown rot under different temperatures and wetness duration.}

The in vivo experiments were performed with isolates ISMf1 (M. fructicola) and ESALQ1 (M. laxa). Peaches of cultivar Dourado, the most important variety grown in São Paulo State, were surface-sterilized by immersion in a $0.5 \%$ sodium hypochlorite solution for 5 minutes. Fruits were rinsed twice, air dried for $24 \mathrm{~h}$, and then placed in plastic containers. Each replicate consisted of a container holding 6 fruit. The fruit were wounded at a single point with a sterile needle $(0.2 \mathrm{~mm})$. For each isolate, $30 \mu \mathrm{L}$ of $10^{5}$ conidia $\mathrm{mL}^{-1}$ suspensions collected from 7-day-old colonies were placed on fruit wounds. Fruit containers were sealed with 
plastic bags to keep relative humidity high and placed in growth chambers at 10, 15, 20, 25 and $30^{\circ} \mathrm{C}$. Each treatment had 3 replications. The same procedure was adopted for the control treatment, in which $30 \mu \mathrm{L}$ of distilled water was placed on each wound. After incubating for 6,12 or $24 \mathrm{~h}$, the plastic bags were removed, and the fruit were maintained at the same temperature until typical symptoms and sporulation were observed.

Disease incidence (number of fruit with symptoms) and disease severity (lesion size) were evaluated daily. Lesion diameter was estimated by the average of two perpendicular measurements of lesion size. Incubation period (time between inoculation and expression of symptoms in $50 \%$ of fruit) and latent period (time between inoculation and sporulation in $50 \%$ of fruit) were estimated. The entire experiment was performed twice.

\section{Data analysis}

The combined effect of temperature and wetness period on conidial germination was analyzed using the beta-monomolecular model: $Z=\left(b_{1}^{*}(T\right.$ $\left.\left.b_{2}\right)^{\wedge} b_{3}{ }^{*}\left(b_{4}-T\right)^{\wedge} b_{5}\right)^{*}\left(1-b_{6}{ }^{*} \exp \left(-b_{7}{ }^{*} M\right)\right)$, in which $Z$ represents the proportion of germinated conidia; $T$ is the temperature $\left({ }^{\circ} \mathrm{C}\right) ; M$ is the wetness period $(\mathrm{h}) ; b_{2}$ and $b_{4}$ are the minimum and maximum temperatures, respectively; $b_{5}$ is a shape parameter, that influences the temperature range around the optimum in which the curve stays near to maximum germination; $b_{7}$ is a rate parameter; and $b_{1}, b_{3}$, and $b_{6}$ are parameters from the model with no biological meaning (HAU \& KRANZ, 1990; BASSANEZI et al., 1998).
Incubation and latent periods of brown rot caused by $M$. fructicola isolate ISMf1 were compared to the incubation and latent periods of the disease caused by isolate ESALQ1 of M. laxa by ANOVA and Tukey's test after square root transformation. Numbers of conidia produced by both isolates were also compared by ANOVA and Tukey's test.

A generalized beta function (BASSANEZI et al., 1998) described by $Y(T)=\{Y \operatorname{opt}[(T-T \mathrm{~min}) /$ $(Y$ opt $-T \min )]^{\wedge}[b 3(T$ opt $-T \min ) /(T \max -T$ opt $\left.)]\right\}$ $[(T \max -T) /(T \max -T \text { opt })]^{\wedge} b 3$ (where Yopt is the lesion diameter at the optimal temperature; Tmin, Topt, and Tmax are the lowest, optimal, and highest temperature for lesion development, respectively; and $b 3$ is the shape parameter) was fitted to the final lesion diameters estimated at each temperature for each isolate by non-linear regression analysis using STATISTICA 6.0 (Statsoft, Tulsa). Equation parameters were compared by $t$ test.

\section{RESULTS}

Conidia germination of Monilinia isolates under different temperatures and wetness duration

M. fructicola conidia germinated at a wide range of temperatures, ranging from 10 to $30^{\circ} \mathrm{C}$. High germination rates were observed for $12 \mathrm{~h}$ and longer wetness periods. Low germination rates (less than $25 \%$ ) were observed at 10 and $30^{\circ} \mathrm{C}$ for the $6 \mathrm{~h}$ wetness period. The beta-monomolecular model provided a good fit to the data (Table 1). The minimum germination temperatures estimated by the model for M. fructicola

Table 1 - Estimated parameters and standard errors (in parenthesis) for the surface curves of germinated conidia (proportion) of Monilinia fructicola (isolates ISMf1, ISMf2, ISMf3 and ISMf4) and M. laxa (isolate ESALQ1) as a function of temperature and wetness periods fitted to a beta-monomolecular model $^{1}$.

\begin{tabular}{|c|c|c|c|c|}
\hline \multirow{2}{*}{$\begin{array}{l}\text { Model parameters } \\
b_{1}\end{array}$} & \multicolumn{2}{|c|}{ 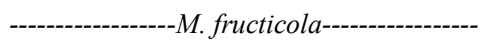 } & \multicolumn{2}{|c|}{--1- } \\
\hline & $0.06(0.013)$ & $\mathrm{A}^{2}$ & $0.21(0.173)$ & A \\
\hline$b_{2}$ & $4.71(0.117)$ & A & $0.00(4.80)$ & A \\
\hline$b_{3}$ & $0.49(0.041)$ & A & $0.34(0.190)$ & A \\
\hline$b_{4}$ & $35.01(0.018)$ & A & $35.00(0.000)$ & A \\
\hline$b_{5}$ & $0.52(0.037)$ & A & $0.18(0.066)$ & B \\
\hline$b_{6}$ & $0.83(0.215)$ & A & $0.71(0.402)$ & A \\
\hline$b_{7}$ & $0.20(0.041)$ & A & $0.23(0.092)$ & A \\
\hline $\mathrm{R}^{2}$ & 0.76 & & 0.82 & \\
\hline
\end{tabular}

${ }^{1} Z=\left(b_{1}{ }^{*}\left(T-b_{2}\right)^{\wedge} b_{3}{ }^{*}\left(b_{4}-T\right)^{\wedge} b_{5}\right)^{*}\left(1-b_{6}{ }^{*} \exp \left(-b_{7}{ }^{*} M\right)\right)$, where $Z$ represents the proportion of germinated conidia, $T$ is the temperature $\left({ }^{\circ} \mathrm{C}\right), M$ is the wetness period (hours), $b_{2}$ and $b_{4}$ are the minimum and maximum temperatures, respectively, $b_{5}$ is a shape parameter, that influences the temperature range around the optimum in which the curve stays near to maximum germination, $b_{7}$ is a rate parameter, and $b_{1}, b_{3}$, and $b_{6}$ are parameters from the model with no biological meaning. ${ }^{2}$ Parameters followed by the same letter in the row are not different by $t$ test $(P<0.05)$. 
and $M$. laxa were $4.7^{\circ} \mathrm{C}$ and $0^{\circ} \mathrm{C}$, respectively. The maximum temperature was $35^{\circ} \mathrm{C}$ for both species (Figure 1, Table 1). Curve parameters were similar for both species, except for $b_{5}$, which was lower for M. laxa.

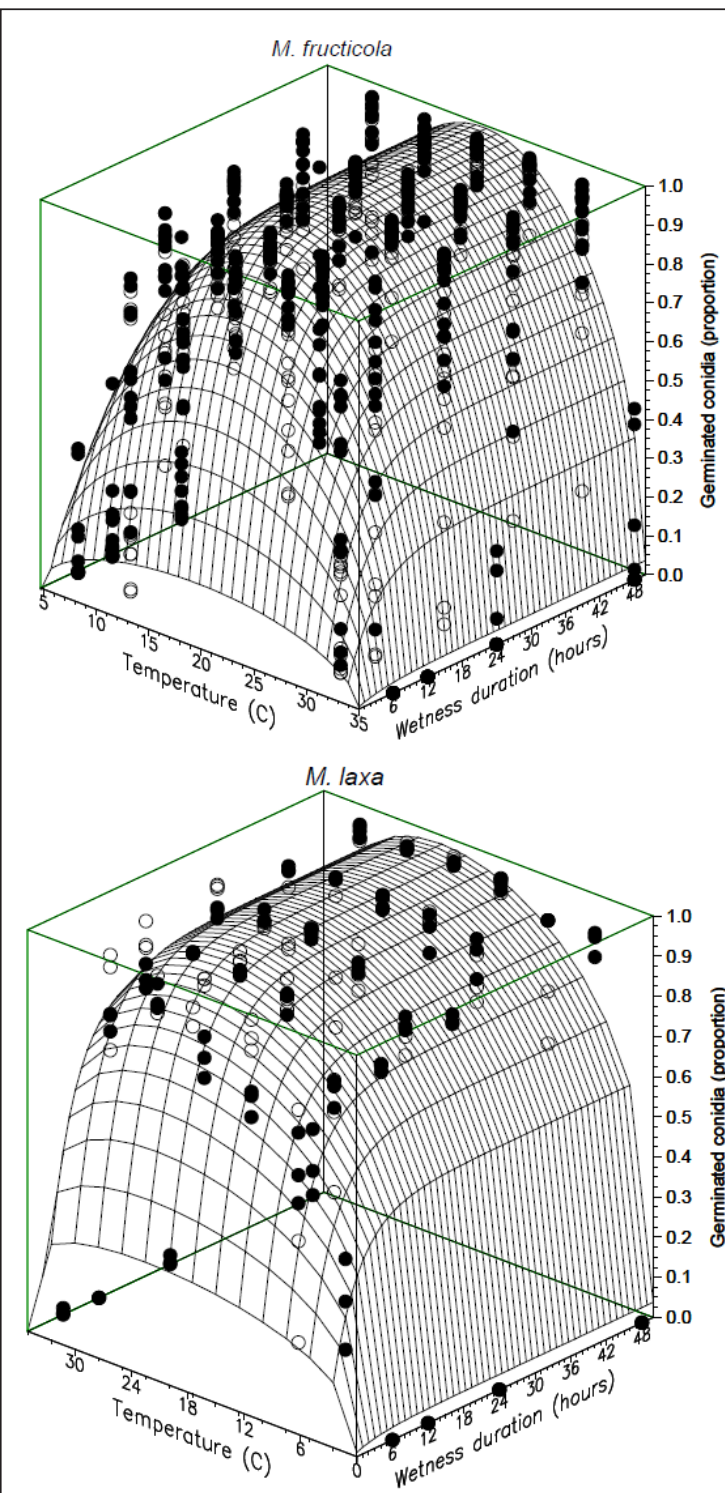

Figure 1 - Surface response of germinated conidia (proportion) of Monilinia fructicola and $M$. laxa generated by the beta-monomolecular model $\left(Z=\left(b_{1}^{*}\left(T-b_{2}\right)^{\wedge} b_{3}{ }^{*}\left(b_{4}-\right.\right.\right.$ $\left.T)^{\wedge} b_{5}\right)^{*}\left(1-b_{6}{ }^{*} \exp \left(-b_{7}{ }^{*} M\right)\right)$, where $Z$ represents the proportion of germinated conidia, $T$ is the temperature $\left({ }^{\circ} \mathrm{C}\right), M$ is the wetness period (h), $b_{2}$ and $b_{4}$ are the minimum and maximum temperatures, respectively, $b_{5}$ is a shape parameter, that influences the temperature range around the optimum in which the curve stays near to maximum germination, $b_{7}$ is a rate parameter, and $b_{1}, b_{3}$, and $b_{6}$ are parameters from the model with no biological meaning). White symbols represent data from the first experiment and black symbols represent data from the second experiment.
Incidence and severity of brown rot for different temperatures and wetness duration

The disease incidence was greater than $80 \%$ for both pathogens in all combinations of temperature and wetness duration (data not shown). Brown rot incubation periods ranged from 2.0 (at $25^{\circ} \mathrm{C}$ ) to 5.7 (at $10^{\circ} \mathrm{C}$ ) days for $M$. fructicola and from 2.5 (at $25^{\circ} \mathrm{C}$ ) to 4.3 (at $10^{\circ} \mathrm{C}$ ) days for M. laxa. Incubation periods of brown rot caused by $M$. fructicola were only higher than the incubation periods for M. laxa at $10^{\circ} \mathrm{C}$ (Table 2). At all other temperatures, there was no difference in incubation periods between pathogens. The brown rot latent periods ranged from 3.7 (at $25^{\circ} \mathrm{C}$ ) to $5.8\left(\right.$ at $30^{\circ} \mathrm{C}$ ) days for $M$. fructicola and from 4.3 (at $20^{\circ} \mathrm{C}$ ) to 8.5 (at $10^{\circ} \mathrm{C}$ ) days for M. laxa. M. fructicola sporulated in less than $50 \%$ of the inoculated fruit at $10^{\circ} \mathrm{C}$, and M. laxa sporulated in less than $50 \%$ of the inoculated fruit at $35^{\circ} \mathrm{C}$ through the end of the experiment (10 days after inoculation). Consequently, the latent period could not be determined for these conditions. There was no difference in latent periods between these pathogens at all other temperatures.

Lesion diameters of brown rot caused by $M$. fructicola and $M$. laxa were significantly influenced by temperature and showed a good fit to the generalized beta function (Table 3). Lesion diameters at the optimum temperature $\left(Y_{\text {opt }}\right)$ were higher for the $M$. laxa isolate than for the $M$. fructicola isolate when 6 and $12 \mathrm{~h}$ of wetness duration were applied after inoculation. However, these differences in lesion diameters were less than $1 \mathrm{~cm}$, and no difference was detected between isolates under $24 \mathrm{~h}$ wetness duration (Table 3). Similarly, the estimated maximum temperature $\left(T_{\text {max }}\right)$ for lesion development was lower for the $M$. laxa isolate than for the M. fructicola isolate by 6 and $12 \mathrm{~h}$ wetness periods after inoculation. With a $24 \mathrm{~h}$ wetness period, the maximum temperature for lesion development was similar (approximately $33^{\circ} \mathrm{C}$ ) for both isolates. Optimum temperature for lesion development under the three wetness periods was significantly lower for the $M$. laxa isolate than for the $M$. fructicola isolate. Other parameters were similar for both isolates.

Sporulation of Monilinia isolates under different temperatures and wetness duration

The number of conidia produced in vitro was highly variable for both Monilinia species, but a difference between species was detected only at $10^{\circ} \mathrm{C}$. At this temperature, M. fructicola produced fewer conidia than M. laxa (data not shown). High conidia production was observed on peach lesions from both species between 15 to $25^{\circ} \mathrm{C}$ (Table 2). 
Table 2 - Average incubation and latent periods (days) for brown rot and number of conidia produced (x $\left.10^{4}\right) \mathrm{mL}^{-1}$ by Monilinia fructicola (isolate ISMf1) and $M$. laxa (isolate ESALQ1) on peaches at different temperatures.

\begin{tabular}{|c|c|c|c|c|c|c|}
\hline \multirow{3}{*}{ Temperature $\left({ }^{\circ} \mathrm{C}\right)$} & \multicolumn{2}{|c|}{ Incubation period (days) } & \multicolumn{2}{|c|}{ Latent period (days) } & \multicolumn{2}{|c|}{ Number of conidia } \\
\hline & M. fructicola & M. laxa & M. fructicola & M. laxa & M. fructicola & M. laxa \\
\hline & (ISMf1) & (ESALQ1) & (ISMf1) & (ESALQ1) & (ISMf1) & (ESALQ1) \\
\hline 10 & $5.7 \mathrm{~B}^{\mathrm{x}}$ & $4.3 \mathrm{~A}$ & $-{ }^{y}$ & $8.5 \mathrm{~B}$ & $2.8 \mathrm{~B}^{\mathrm{x}}$ & $14.6 \mathrm{~A}$ \\
\hline 15 & $3.2 \mathrm{~A}$ & $3.3 \mathrm{~A}$ & $5.7 \mathrm{~A}$ & $5.3 \mathrm{~A}$ & $22.9 \mathrm{~A}$ & $22.5 \mathrm{~A}$ \\
\hline 20 & $2.2 \mathrm{~A}$ & $2.5 \mathrm{~A}$ & $4.0 \mathrm{~A}$ & $4.3 \mathrm{~A}$ & $15.9 \mathrm{~A}$ & $20.2 \mathrm{~A}$ \\
\hline 25 & $2.0 \mathrm{~A}$ & $2.5 \mathrm{~A}$ & $3.7 \mathrm{~A}$ & $4.7 \mathrm{~A}$ & $19.5 \mathrm{~A}$ & $19.8 \mathrm{~A}$ \\
\hline 30 & $2.7 \mathrm{~A}$ & $2.7 \mathrm{~A}$ & $5.8 \mathrm{~A}$ & $-\mathrm{y}^{\mathrm{y}}$ & $5.1 \mathrm{~A}$ & $2.6 \mathrm{~B}$ \\
\hline
\end{tabular}

${ }^{\bar{x}}$ Means in each row followed by the same letters do not differ according to ANOVA and Tukey test $(P<0.05)$. Data are means of two sets and are original but for the mean test they were transformed by square root. ${ }^{\mathrm{y}}$ Sporulation was detected in less than $50 \%$ of the inoculated fruit; latent period was greater than 9 days.

However, variability in the number of conidia produced was very high in this temperature range. The M. laxa isolate produced more conidia than the M. fructicola isolate at $10^{\circ} \mathrm{C}$ and fewer at $30^{\circ} \mathrm{C}$. At other temperatures, there was no difference in conidia production between species (Table 2).

\section{DISCUSSION}

Results of this study demonstrated that the optimum temperature estimated for brown rot development caused by M. laxa is lower than that estimated for $M$. fructicola. Additionally, at low temperatures, the number of conidia produced in brown rot lesions was higher for M. laxa than for M. fructicola. Conversely, at high temperatures $M$. fructicola lesions produced more conidia than $M$. laxa lesions, and the estimated maximum temperature for lesion development was higher for M. fructicola than for M. laxa. This occurred despite the fact that no differences in conidia germination were detected between species across different temperature and wetness settings.

For both Monilinia species, high conidia germination rates $(>50 \%)$ were observed for $6 \mathrm{~h}$ of wetness in the range of $15-25^{\circ} \mathrm{C}$, and the maximum rates occurred for $12 \mathrm{~h}$. The optimal temperature and wetness duration ranges for germination were similar to those previously observed for M. laxa (TAMM \& FLÜCKIGER, 1993) and M. fructicola (WEAVER, 1950; PHILLIPS, 1982; CASALS et al., 2010). Parameters estimated by the beta generalized function were similar for both Monilinia species, except for the shape parameter $\left(b_{5}\right)$, showing that the

Table 3 - Parameters and standard errors (in parenthesis) from a generalized beta function ${ }^{1}$ fitted to brown rot lesion diameter for Monilinia fructicola (ISMf) and M. laxa (ESALQ1), with three wetness duration (hours).

\begin{tabular}{|c|c|c|c|c|c|c|}
\hline \multirow{2}{*}{$\begin{array}{l}\text { Temp } \\
\left({ }^{\circ} \mathrm{C}\right)\end{array}$} & \multicolumn{2}{|c|}{ 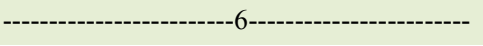 } & \multicolumn{2}{|c|}{-------------------------12------------------------ } & \multicolumn{2}{|c|}{--------------------24-------------------- } \\
\hline & $\begin{array}{l}\text { M. fructicola } \\
\text { ISMf1 }\end{array}$ & $\begin{array}{l}\text { M. laxa } \\
\text { ESALQ1 }\end{array}$ & $\begin{array}{l}\text { M. fructicola } \\
\text { ISMf1 }\end{array}$ & $\begin{array}{l}\text { M. laxa } \\
\text { ESALQ1 }\end{array}$ & $\begin{array}{l}\text { M. fructicola } \\
\text { ISMf1 }\end{array}$ & $\begin{array}{c}\text { M. laxa } \\
\text { ESALQ1 }\end{array}$ \\
\hline$Y_{\text {opt }}$ & $7.46 \mathrm{~A}^{2}(0.251)$ & 8.27 B $(0.324)$ & 7.22 A (0.289) & 8.12 B $(0.272)$ & 7.66 A (0.268) & $7.61 \mathrm{~A}(0.367)$ \\
\hline$T_{\min }$ & 8.36A (1.286) & 7.99 A (0.002) & 7.93 A (1.419) & 7.99 A (0.002) & 7.49 A (1.369) & $7.99 \mathrm{~A}(0.002)$ \\
\hline$T_{\text {opt }}$ & 24.48 B (0.488) & 19.84 A (1.406) & 23.23 B $(0.531)$ & 20.73 А (1.241) & $22.81 \mathrm{~B}(0.502)$ & $16.93 \mathrm{~A}(1.58)$ \\
\hline$b_{3}$ & $0.36 \mathrm{~A}(1.105)$ & $0.50 \mathrm{~A}(0.177)$ & 0.43 A (0.116) & 0.34 A (0.154) & $0.510 \mathrm{~A}(0.108)$ & $0.69 \mathrm{~A}(0.207)$ \\
\hline$T_{\max }$ & $33.00 \mathrm{~B}(0.001)$ & 31.32 A (0.748) & $33.00 \mathrm{~B}(0.001)$ & $30.47 \mathrm{~A}(0.657)$ & $33.00 \mathrm{~A}(0.001)$ & $32.30 \mathrm{~A}(0.86)$ \\
\hline
\end{tabular}

${ }^{I} Y(T)=\left\{Y_{\text {opt }}\left[\left(T-T_{\min }\right) /\left(Y_{\text {opt }}-T_{\min }\right)\right]^{\wedge}\left[b 3\left(T_{\text {opt }}-T_{\min }\right) /\left(T_{\max }-T_{\mathrm{opt}}\right)\right]\right\}\left[\left(T_{\max }-T\right) /\left(T_{\max }-T_{\mathrm{opt}}\right)\right]^{\wedge} b 3$, where $Y_{\text {opt }}$ is the lesion diameter at the optimal temperature, $T_{\min }, T_{\mathrm{opt}}$, and $T_{\max }$ are, respectively, the lowest, optimal, and highest temperature for lesion development, and $b 3$ is the shape parameter. ${ }^{2}$ Parameters followed by the same letter in the row within each wetness duration are not different by $t$ test $(P<0.05)$. 
range of temperatures and wetness periods favourable for germination is greater for $M$. laxa than for $M$. fructicola. In Brazil, a $6 \mathrm{~h}$ wetness period at 15$25^{\circ} \mathrm{C}$ occurs frequently during peach season in most areas of peach production (GARRIDO et al., 2011). Consequently, no restraint will be imposed on the conidia germination of M. laxa in Brazilian conditions, and forecast systems for brown rot based on these variables (range of temperatures and wetness periods favourable for germination) should not be useful.

For all monocyclic components of brown rot assessed in this study, high temperatures favoured $M$. fructicola, and low temperatures favoured $M$. laxa. The incubation and latent periods of brown rot under optimum conditions $\left(20-25^{\circ} \mathrm{C}\right)$ were short for both pathogens, as already stated by BIGGS \& NORTHOVER (1988a), but at $10^{\circ} \mathrm{C}$, the incubation and latent periods were shorter for M. laxa than for $M$. fructicola. Similarly, the estimated temperatures for the maximum lesion diameter of $M$. laxa were $3-5^{\circ} \mathrm{C}$ below those of $M$. fructicola, regardless of wetness duration. Under the optimum wetness duration (24h), the brown rot lesion diameters were similar for both species, as observed by PIZZUOLO et al. (2006). Low temperatures inhibited $M$. fructicola lesion development four-fold more than to M. laxa.

Although, there are many reports concerning different monocyclic components of $M$. laxa (PIZZUOLO et al., 2006) and M. fructicola (BIGGS \& NORTHOVER, 1988a; 1988b; NORTHOVER \& BIGGS, 1990; FOURIE \& HOLZ, 2003; LUO \& MICHAILIDES, 2003; PIZZUOLO et al., 2006), none of them analyzed how environmental variables affect each monocyclic component. Methodologies used in different reports are highly variable. For instance, the disease has been described on different hosts, such as cherry (BIGGS \& NORTHOVER, 1988b; NORTHOVER \& BIGGS, 1990), nectarine (FOURIE \& HOLZ, 2003), peach (BIGGS \& NORTHOVER, 1988a; PIZZUOLO et al., 2006) and prune (LUO \& MICHAILIDES, 2003), and in different plant organs (BIGGS \& NORTHOVER, 1988a). The inoculation method with (LUO \& MICHAILIDES, 2003) or without (PIZZUOLO et al., 2006) wounds and the environmental conditions are distinct in the different reports. The comparison performed in our research showed that M. laxa is as aggressive as M. fructicola on peach fruit under optimal conditions and can be favoured by temperatures lower than $15^{\circ} \mathrm{C}$. The population shift of Monilinia spp. observed in the USA (MICHAILIDES et al., 1987) was most likely due to the benomyl resistance of $M$. fructicola and somewhat the environmental preferences of $M$. laxa rather than its aggressive behaviour.
As observed in our study; although, $M$. fructicola shares some features with $M$. laxa, differences in ecological requirements and host plant preferences are reported from areas where these species co-exist (EFSA, 2011). In these areas, M. fructicola is mostly reported on fruit, whereas $M$. laxa is mostly prevalent on blossoms and twigs (EFSA, 2011). This differentiation could be explained by differences in weather conditions during flowering and fruit ripening, as the former occurs at spring at low temperatures, and the latter occurs in summer when temperatures are high. Peach production in Brazil is concentrated in the Southern region, where low temperatures are frequent (GARRIDO et al., 2011) and $M$. laxa could cause epidemic during blooming in this region. The impact of M. laxa in Brazil should be investigated by monitoring the species entrance in the country and prevalence of the species in São Paulo State, where M. laxa where first reported.

\section{ACKNOWLEDGEMENTS}

The authors would like to thank Fundação de Amparo a Pesquisa do Estado de São Paulo (FAPESP) for its financial support (2003/10025-9) and for the scholarship granted to the first author (2007/52147-4) and Silvia A. Lourenço for their assistance in conducting the experiments.

\section{REFERENCES}

BASSANEZI, R.B. et al. Effects of bean line pattern mosaic virus on the monocyclic components of rust and angular leaf spot of Phaseolus bean at different temperatures. Plant Pathology, v.47, p.289-298, 1998. Available from: <http://onlinelibrary.wiley.com/ doi/10.1046/j.1365-3059.1998.00239.x>.Accessed: Feb, 22, 2017. doi:10.1046/j.1365-3059.1998.00239.x.

BIGGS, A.R.; NORTHOVER, J. Influence of temperature and wetness duration on infection of peach and sweet cherry fruits by Monilinia fructicola. Phytopathology, v.78, p.1352-1356, 1988a. Available from: $<$ https://www.apsnet.org/publications/phytopathology/backissues/ Documents/1988Articles/Phyto78n10_1352.PDF>.Accessed: Feb, 22, 2017.

BIGGS, A.R.; NORTHOVER, J. Early and late-season susceptibility of peach fruits to Monilinia fructicola. Plant Disease, v.72, p.1070-1074, 1988b. Available from: <https://www.apsnet.org/ publications/plantdisease/backissues/Documents/1988Articles/ PlantDisease72n12_1070.PDF>. Accessed: Feb, 23, 2017.

CASALS, C. et al. Effect of temperature and water activity on in vitro germination of Monilinia spp. Journal of Applied Microbiology, v.108, p.47-54, 2010. Available from: <http:// apsjournals.apsnet.org/doi/pdf/10.1094/PDIS.1998.82.2.195>. Accessed: Feb, 23, 2017. doi: pdf/10.1094/PDIS.1998.82.2.195.

CÔTÉ, M.-J. et al. Identification of Monilinia fructigena, M. fructicola, M. laxa, and Monilia polystroma on inoculated and naturally infected fruit using multiplex PCR. Plant Disease, v.8, p.1219-1225, 2004. Available from: <https://www.apsnet.org/ publications/plantdisease/backissues/Documents/1988Articles/ PlantDisease72n12_1070.PDF>. Accessed: Feb, 22, 2017. 
EFSA. Panel on plant health: pest risk assessment of Monilinia fructicola for the EU territory and identification and evaluation of risk management options. EFSA Journal, v.9, p.2119, 2011. Available from: < http://www.efsa.europa.eu/efsajournal>. Accessed: Mar. 20, 2014. doi: 10.2903/j.efsa.2011.2119.

FOURIE, P.H.; HOLZ, G. Germination of dry, airborne conidia of Monilinia laxa and disease expression on nectarine fruit. Australasian Plant Pathology, v.32, p.9-18, 2003. Available from: <http://link. springer.com/article/10.1071/AP02063>. Accessed: Feb, 22, 2017. doi: 10.1071/AP02063.

GARRIDO, L.R. et al. Impacto das mudanças climáticas globais sobre as doenças de fruteiras de caroço no Brasil. In: GHINI, R. et al. Impactos das mudanças climáticas sobre doenças de importantes culturas no Brasil. Jaguariúna: Embrapa Meio Ambiente, 2011. p.227-248. Available from: <file:///C:/Users/ufpr/Downloads/ ImpactoMudancasClimaticas.pdf $>$. Accessed: Feb, 22, 2017.

HAU, B.; KRANZ, J. Mathematics and statistics for analyses in epidemiology. In: KRANZ, J. (Ed.). Epidemics of plant diseases. Berlin: Springer-Verlag, 1990. p.12-52.

LICHTEMBERG, P.S.F. et al. Comparison of the sensitivity of Monilinia fructicola isolates to tebuconazole in Brazil using three methods. Canadian Journal of Plant Pathology, v.38, n.1, p,19, 2016. Available from: <http://www.tandfonline.com/doi/full/1 $0.1080 / 07060661.2016 .1147496$ ? scroll=top\&needAccess $=$ true $>$. Accessed: Mar. 16, 2016. doi: 10.1080/07060661.2016.1147496.

LUO, Y:; MICHAILIDES, T.J. Threshold conditions that lead latent infection to prune fruit rot caused by Monilinia fructicola. Phytopathology, v.93, p.102-111, 2003. Available from: <http:/ apsjournals.apsnet.org/doi/pdf/10.1094/PHYTO.2003.93.1.102>. Accessed: Mar. 16, 2016.

MAY-DE MIO, L.L. et al. Sensitivity of Monilinia fructicola from Brazil to tebuconazole, azoxystrobin, and thiophanate-methyl and implications for disease management. Plant Disease, v.95, p.821827, 2011. Available from: <http://apsjournals.apsnet.org/doi/ pdf/10.1094/PDIS-07-10-0511>. Accessed: Mar. 16, 2016. doi: 10.1094/PDIS-07-10-0511.

MICHAILIDES, T.J. et al. Shift of Monilinia spp. and distribution of isolates sensitive and resistant to benomyl in California prune and apricot orchards. Plant Disease, v.71, p.893-896, 1987. Available from: <http://www.apsnet.org/publications/PlantDisease/ BackIssues/Documents/1987Articles/PlantDisease71n10 893. PDF>. Accessed: Feb, 20, 2017.

NORTHOVER, J.; BIGGS, A.R. Susceptibility of immature and mature sweet and sour cherries to Monilinia fructicola. Plant Disease, v.74, p.280-284, 1990. Available from: <http://www.apsnet.
org/publications/plantdisease/backissues/Documents/1990Articles/ PlantDisease74n04_280.PDF>. Accessed: Feb, 20, 2017.

OGAWA, J.M. et al. Brown rot. In: OGAWA, J.M. et al. Compendium of stone fruit disease. Saint Paul: APS, 1995. p.7-10.

PHILLIPS, D.J. Changes in conidia of Monilinia fructicola in response to incubation temperature. Phytopathology, v.72, p.1281-1283, 1982. Available from: <https://www.apsnet.org/ publications/phytopathology/backissues/Documents/1982Articles/ Phyto72n10_1281.pdf>. Acessed: Feb, 20, 2017.

PHILLIPS, D.J. Effects of temperature on Monilinia fructicola conidia produced on fresh stone fruits. Plant Disease, v.68, p.610-612, 1984. Available from: <https://www.apsnet.org/ publications/PlantDisease/BackIssues/Documents/1984Articles/ PlantDisease68n07_610.PDF>. Accessed: Feb, 23, 2017.

PIZZUOLO, P.H. et al. Variations in the molecular and physiological characteristics and the virulence of Monilinia fructicola, $M$. fructigena and M. laxa isolates. Phytopathologia Mediterranea, v.45, p.139-152, 2006. Available from: <http://www.fupress.net/ index.php/pm/article/view/1825/1760>. Accessed: Feb, 20, 2017. doi: dx.doi.org/10.14601/Phytopathol_Mediterr-1825.

SOUZA, D.C. et al. First report of Monilinia laxa causing brown rot on peaches in Brazil. Phytopathology, v.98, p.S148, 2008. Available from: <http://apsjournals.apsnet.org/doi/pdf/10.1094/ PHYTO.2008.98.6.S9>. Accessed: Feb, 24, 2017.

TAMM, L.; FLÜCKIGER, W. Influence of temperature and moisture on growth, spore production, and conidial germination of Monilinia laxa. Phytopathology, v.83, p.1321-1326, 1993. Available from: $<$ https://www.apsnet.org/publications/phytopathology/backissues/ Documents/1993Articles/Phyto83n12_1321.PDF>.Accessed: Feb, 20, 2017.

VILLARINO, M. et al. Secondary inoculum dynamics of Monilinia spp. and relationship to the incidence of postharvest brown rot in peaches and the weather conditions during the growing season. European Journal of Plant Pathology, v.133, p.585-598, 2012. Available from: $<$ https:// link.springer.com/article/10.1007/s10658-011-9931-y>. Accessed: Feb, 20, 2017. doi: 10.1007/s10658-011-9931-y.

WATSON, W.A. et al. Influence of temperature and wetting period on inoculum production by Monilinia fructicola in peach twig cankers. Plant Disiase, v.86, p.666-668, 2002. Available from: $<$ https://link.springer.com/article/10.1007/s10658-011-9931-y> Accessed: Feb, 20, 2017.

WEAVER, L.O. Effect of temperature and relative humidity on occurrence of blossom blight of stone fruits. Phytopathology, v.40, p.1136-1153, 1950. Available from: <https://www.cabdirect. org/cabdirect/abstract/19511100905> . Accessed: Feb, 24, 2017. 